\title{
Evaluation of the Strategic Leadership Characteristics of Provincial Directors of Youth and Sports in Terms of Some Variables
}

\author{
ALBAYRAK, Ahmet Yilmaz \\ Sport Management, Gumushane University \\ School of Physical Education and Sport, Gümüşhane University, Turkey \\ Tel: +905333778088 E-mail: ahmetyilmazalbayrak@hotmail.com \\ ORCID:000- 0002- 3345- 6579
}

TEZCAN, Efecan

Sport Management, Gumushane University

School of Physical Education and Sport, Gümüşhane University, Turkey

Tel: +905531788988Ｅ-mail: efecantezcan@gmail.com

ORCID: 0000- 0003- 3284- 6361

MUTLU, Tonguç Osman

Sport Management, Mugla Sitkı Kocman University

Spor Sciences Faculty, Mugla Sitk1 Kocman University, Turkey

Tel: +905353978189 E-mail: omutlu@ @u.edu.tr

ORCID: 0000- 0003- 1270- 6978

BAYRAKDAROĞLU, Yeşim

Sport Management, Gumushane University

School of Physical Education and Sport, Gümüşhane University, Turkey

Tel: +905432630461 E-mail: yesimsongun@ hotmail.com

ORCID: 0000- 0003- 1460- 4780 
Received: September 14, 2021 Accepted: November 3, 2021 Published: November 17, 2021

doi: $10.5296 /$ jsss.v8i2.19212

URL: https://doi.org/10.5296/jsss.v8i2.19212

\begin{abstract}
This study aims to examine the strategic leadership characteristics of Provincial Directors of Youth and Sports in terms of some variables. The sample group consists of 59 people serving as Provincial Directors of Youth and Sports in Turkey. The Strategic Leadership Questionnaire was used to collect data. SPSS 22.0 program was utilized to analyze the data obtained. According to demographic variables, one-way analysis of variance (One way Anova), Independent T-test and Pearson correlation analysis were used to compare the scores of the strategic leadership scale sub-dimension of the provincial directors of youth and sports participating in the study. As a result of the analyses, it has been determined that the provincial directors of youth and sports participating in the study use high levels of transformational leadership and managerial leadership, their ethical leadership and political leadership use levels are above the moderate level and their leadership effectiveness perceptions and corporate environment perceptions are above the moderate level. There is a positive relationship between Transformational leadership, Managerial leadership, Ethical leadership, Political leadership and Leadership effectiveness ( $p<0.05)$. However, there is no significant relationship between corporate environment perception and leadership effectiveness ( $p>0.05$ ). There is a positive relationship between perception level and corporate environment perception and it is below average $(p<0.05)$.
\end{abstract}

\title{
1. Introduction
}

Sport is a vital part of the culture and fabric of society. After analyzing the culture of society, one should know the priority of the factors that may have an impact on society and how well sport is managed to seize any opportunity or confront any threat. This gets complicated with the nature of sport desiring "success" for sports organizations. Doing business, producing services and managing is naturally competitive just like sports. Sports organizations that do not develop and implement appropriate strategies and tactics in response to the needs of changing conditions and services face the risk of stagnation, failure and possible loss of wealth (Parker, 2004: 220).

The term "organization" implies and defines that there is a some kind of structure and order in the way things are done. Centering on the idea that organizations are entities with which individuals coordinate their actions to achieve certain goals, directors use organizational theories about ways to organize work in their department (division of labor) every day and how work should be coordinated with work in other departments (integration) without notice and they think about how to create a work environment that encourages organizational members to work together towards goals (Ann and Cunliffe, 2008: 3). Each of these directors faces common challenges in finding ways to help the organization achieve its goals.

Understanding how individual, group and organizational characteristics affect and shape working attitudes and behaviors, a director can implement different management practices to 
see if changing one or more of these characteristics increases the effectiveness of the organization, the individuals and groups it contains (George and Jones, 2012).

In the field of sports management and sports services, great effort is often required to guide a determined group of people towards a common identifiable goal, and leadership is also the key to the successful management of sports practices (Watt, 1998:72-73). Strong leadership perception, conveyed through the ages, is seen as the ability to stimulate and direct support and commitment to a cause. Leadership ensures the organization to drive and direct towards its goals along a chosen route. There are certain qualities that are distinguishing characteristics of good leaders and these are defined as integrity, enthusiasm, warmth, calmness, fairness and satiety (Torkildsen, 2005: 419).

For this reason, it should be no surprise that leadership is a key entry. Leadership is an important component for achieving managerial success and goals at all organizational levels. The director's personal leadership style - that is, specific ways a director chooses to influence other people - shapes the director's approach and strategy to planning, organizing and supervising (other core roles of management) to help achieve these goals (Jones and George, 2016: 412).

Strategy is the ability to connect long-range visions and concepts to daily work, and an organization's management strategy will determine the direction of the organization, how the organization will manage environmental demands, the internal organizational processes and practices necessary to achieve the goals (Ann and Cunliffe, 2008: 3). Strategy is the ability to connect long-range visions and concepts to daily work, and an organization's management strategy will determine the direction of the organization, how the organization will manage environmental demands, and the internal organizational processes and practices necessary to achieve the goals. Strategy is a critical skill that strategic leaders use in determining the strategic direction of the organization, not creating or communicating it to others. Strategic leaders have the ability to turn strategy into action. Therefore, strategic leadership is related to 'the development of the organization as a whole including its changing goals and capabilities' (Davies and Davies; 2004; 30-32).

Strategic leadership means creating a general sense of purpose and direction and making strategic decisions that are integrated in the organization, guiding strategy formulation and implementation. The processes by which such decisions are made become tools for individuals and groups to shape organizational strategies (Shrivastava and Sidney; 1989:52).

Among the activities often associated with strategic leadership are making strategic decisions, creating and communicating a vision for the future, development of key competencies and capabilities, improving organizational structures, processes and controls, maintaining an effective organizational culture and instilling ethical value systems into an organization's culture which state that "strategic leadership focuses on creating meaning and purpose for the organization" (Boal and Hooijberg, 2001: 516). Strategic leadership is defined as "the ability (also wisdom) to make appropriate decisions about goals (aims), paths (strategies) and means (actions) in an uncertain environment". Strategic leaders can live in an environment full of uncertain roles, contradictions, and uncertainties and view change as opportunities and challenges. These strategic leaders guide a process that scans the environment for themes and 
forces while establishing a set of shared aspirations, values and beliefs that determine the direction of the organization with the environment, and adapt their strategies and actions to the ever-changing internal and external environment (Pisapia, 2006: 13).

The strategic leader in the sports organization should develop an overall mission for the purposes of the sports organization while determining the various strategic choices s/he can make in the search for a particular strategic direction and what the direction should be. This is usually related to the organization's values and what it believes, the organization's behavioral standards and general philosophy and how the strategy and the organization position themselves in relation to the competitors (Wiscombe, 2009: 72).

As a consequence, strategic leadership has emerged as one of the most critical elements for success not only in sports organizations, but in all of them and sports organizations are in a never-ending search for those who have the ability to lead effectively. Nowadays, strategic leadership is a very important component of Provincial Directors of Youth Services and Sports, which provide sports services as in all sports organizations due to the fact that the sports world has become more competitive and more variable (Covell et al., 2007: 252).

\section{Material and Method}

The main aims of this study are to determine;

- Whether the personal and organizational characteristics of provincial directors of youth services and sports and their use of strategic leadership are effective on the personal accomplishment feeling of the provincial directors of youth services and sports,

- Personal and organizational characteristics that affect the use of the strategic leadership characteristics of the provincial directors of youth services and sports,

- To what extent the provincial directors of youth services and sports use strategic leadership characteristics.

\section{Research Population and Sample}

This is a scanning modelled research. The research population is composed of the 81 Provincial Directors of Youth Services and Sports working in 2019-2020. The following measurement tools have been applied to the 59 of these Provincial Directors of Youth Services and Sports.

\section{Data Collection Tools of the Research}

In order to collect the data, the questionnaire technique being one of the data collection techniques used in quantitative studies was used to obtain the opinions of the provincial directors of youth and sports (Sönmez and Alacapınar, 2018: 187). As a result of the literature study, the Strategic Leadership Scale (SLS) which complied with the research purpose most and developed by Guerra and Pisapia and adapted into the Turkish language and culture was used. SLS is composed of four parts. The first part contains personal and demographic information of the participants. The second part is the five point Likert type scale composed 
of 64 questions which aims to measure the leadership characteristics. Every leadership characteristic is concluded with 16 questions. Every leadership characteristic is evaluated with 16 questions. In the third part, ten questions were asked to the provincial directors in order to question their opinions about the personal achievement of the leader. The fourth part contains 12 questions about the environment of the organization (corporate environment structure).

The questionnaire was used as is in the doctoral dissertation titled "Evaluation of the Strategic Leadership Characteristics of Hospital Managers" conducted by Özgür UĞURLUOĞLU in 2009. Considering the Cronbach alpha coefficient calculated according to the answers given by 440 hospital managers to the SLS sub-dimension within the scope of this study, transformational leadership is .878 , managerial leadership is .829 , and ethical leadership is .814 , political leadership is .816 and perception of success is .897 and .910 for all 86 questions. In studies conducted in Turkey, the dimensions in the scale were used as management managerial (administrative) leadership and bonding - ethical (ethics) leadership, bridging - political (politics) leadership, transforming (transformational) leadership; interaction - relational (effective) leadership (Altınkurt 2007; Aydın, 2012; Elma, 2010; Kılınçkaya, 2013; Uğurluoğlu, 2009; Ülker, 2009, Çoban et al. 2019: 131).

\section{Statistical Methods Used in the Research}

SPSS 22.0 program was used to analyze the data obtained. Parametric analysis was used in the comparison of the strategic leadership scale sub-dimension scores of the participant provincial directors of youth and sports according to demographic variables since the data were suitable for the normal distribution. One-way analysis of variance (One Way Anova) was used to compare the scale sub-dimension scores according to age group, professional working period and working period as a director and Independent T-test (independent T-test) was used to compare the scale sub-dimension scores according to education level. In order to test the relation among the sub-dimensions of the scale, Pearson correlation analysis was used. According to the results of the reliability analysis results, Cronbach's Alpha internal consistency coefficients for sub-dimensions were found as (.792) for transformational leadership, (.881) for managerial leadership, (.792) for ethical leadership, (.755) for political leadership, (.917) for leader effectiveness and (.610) for corporate environment.

\section{Findings}

Table 1. Frequency and Percentage Distribution of the Participant Provincial Directors of Youth and Sports Regarding Demographic Information

\begin{tabular}{cccc}
\hline Variable & Sub-variable & f & \% \\
\hline & $28-35$ & 5 & 8.5 \\
Age group & $36-43$ & 17 & 28.8 \\
& $44-50$ & 25 & 42.4 \\
Education & 51 and over & 12 & 20.3 \\
& Undergraduate & 43 & 72.9 \\
Professional working & Graduate & 16 & 27.1 \\
period & $12-17$ & 19 & 32.2 \\
& $18-23$ & 23 & 39.0
\end{tabular}




\begin{tabular}{cccc}
\hline & $23+$ & 17 & 28.8 \\
Working period as a & $0-3$ & 18 & 30.5 \\
director & $4-7$ & 18 & 30.5 \\
& $8-11$ & 13 & 22.0 \\
& $11+$ & 10 & 16.9 \\
\hline
\end{tabular}

$8.5 \%$ of the provincial directors of youth and sports participating in the study are in the 28-35 age group, $28.8 \%$ in the $36-43$ age group, $42.4 \%$ in the $44-50$ age group, $20.3 \%$ in the 51 and over and $72.9 \%$ of them have undergraduate degree, $27.1 \%$ have graduate degree. $32.2 \%$ of the participant directors have been working for 12-17 years, 39\% of them have been working for $18-23$ years, $28.8 \%$ have been working for $23+$ years and $30.5 \%$ are directors for $0-3$ years, $30.5 \%$ have been working as a director for $4-7$ years, $22 \%$ of them for $8-11$ years and $16.9 \%$ of them have been working as a director for $11+$ years.

Table 2. Descriptive Statistics of the Strategic Leadership Scale Sub-dimension Scores of the Participant Provincial Directors of Youth and Sports

\begin{tabular}{cccc}
\hline Sub-dimension & N & X & Sd \\
\hline Transformational & 59 & 4.34 & .332 \\
leadership & 59 & 4.40 & .409 \\
Managerial leadership & 59 & 4.07 & .392 \\
Ethical leadership & 59 & 3.94 & .417 \\
Political leadership & 59 & 3.81 & .600 \\
Leadership effectiveness & 59 & 3.63 & .395 \\
Corporate environment & & & \\
\hline
\end{tabular}

It is observed that the participant provincial directors of youth and sports have high levels of transformational leadership and managerial leadership use, their ethical and political leadership use levels are above the moderate level, and their leadership effectiveness perceptions and corporate environment perceptions are above the moderate level.

Table 3. Comparison of the Strategic Leadership Scale Sub-dimension Scores of the Participant Provincial Directors of Youth and Sports by the Age Group

\begin{tabular}{|c|c|c|c|c|c|c|c|}
\hline Sub-dimension & $\begin{array}{l}\text { Age } \\
\text { group }\end{array}$ & $\mathbf{N}$ & $\mathbf{X}$ & Sd & $\mathbf{F}$ & $\mathbf{p}$ & $\begin{array}{l}\text { Intergroup } \\
\text { differences }\end{array}$ \\
\hline \multirow{4}{*}{$\begin{array}{l}\text { Transformational } \\
\text { leadership }\end{array}$} & $28-35$ & 5 & 3.96 & 0.31 & \multirow{4}{*}{4.483} & \multirow{4}{*}{.007} & \multirow{4}{*}{$28-35<44-50$} \\
\hline & $36-43$ & 17 & 4.33 & 0.26 & & & \\
\hline & $44-50$ & 25 & 4.48 & 0.31 & & & \\
\hline & $50+$ & 12 & 4.26 & 0.34 & & & \\
\hline \multirow{4}{*}{$\begin{array}{l}\text { Managerial } \\
\text { leadership }\end{array}$} & $28-35$ & 5 & 4.05 & 0.59 & \multirow{4}{*}{2.545} & \multirow{4}{*}{.065} & \multirow{5}{*}{ - } \\
\hline & $36-43$ & 17 & 4.30 & 0.39 & & & \\
\hline & $44-50$ & 25 & 4.52 & 0.34 & & & \\
\hline & $50+$ & 12 & 4.44 & 0.42 & & & \\
\hline \multirow{4}{*}{$\begin{array}{l}\text { Ethical } \\
\text { leadership }\end{array}$} & $28-35$ & 5 & 3.90 & 0.35 & \multirow{4}{*}{.810} & \multirow{4}{*}{.494} & \\
\hline & $36-43$ & 17 & 4.00 & 0.37 & & & \multirow{3}{*}{ - } \\
\hline & $44-50$ & 25 & 4.14 & 0.42 & & & \\
\hline & $50+$ & 12 & 4.11 & 0.39 & & & \\
\hline \multirow{4}{*}{$\begin{array}{l}\text { Political } \\
\text { leadership }\end{array}$} & $28-35$ & 5 & 3.84 & 0.44 & \multirow{4}{*}{1.207} & \multirow{4}{*}{.316} & \multirow{4}{*}{-} \\
\hline & $36-43$ & 17 & 3.80 & 0.46 & & & \\
\hline & $44-50$ & 25 & 4.01 & 0.40 & & & \\
\hline & $50+$ & 12 & 4.04 & 0.36 & & & \\
\hline
\end{tabular}




\begin{tabular}{cccccccc}
\hline & $28-35$ & 5 & 3.60 & 0.80 & & & \\
Leadership & $36-43$ & 17 & 3.72 & 0.53 & 2.065 & .115 & - \\
effectiveness & $44-50$ & 25 & 4.02 & 0.52 & & & \\
& $50+$ & 12 & 3.58 & 0.69 & & & \\
Corporate & $28-35$ & 5 & 3.87 & 0.19 & & & $28-35>50+$, \\
environment & $36-43$ & 17 & 3.70 & 0.37 & 2.850 & .046 & $36-43>50+$, \\
& $44-50$ & 25 & 3.66 & 0.41 & & & $44-50>50+$ \\
\hline
\end{tabular}

Looking at Table 3, it has been observed that there is no statistically significant difference in the managerial leadership, ethical leadership, political leadership use and leadership effectiveness perception levels of the participant provincial directors of youth and sports $(\mathrm{p}>$ 0.05), their levels of transformational leadership use and corporate environment perception levels have presented statistically significant difference according to age groups $(\mathrm{p}<0.05)$. In the transformational leadership sub-dimension, directors being in the 44-50 age group have been found to be significantly more transformational than those in the 28-35 age group (p $<0.05)$. In terms of corporate environment perception, directors in the age groups of 26-35, 36-43 and 44-50 have a higher corporate environment perception compared to the $50+$ age group at statistically significant level $(\mathrm{p}<0.05)$.

Table 4. Comparison of the Strategic Leadership Scale Sub-dimension Scores of the Participant Provincial Directors of Youth and Sports by the Education

\begin{tabular}{ccccccc}
\hline Sub-dimension & Education & $\mathbf{N}$ & $\mathbf{X}$ & $\mathbf{S d}$ & $\mathbf{t}$ & $\mathbf{p}$ \\
\hline Transformational & Undergraduate & 43 & 4.29 & 0.30 & -2.152 & .036 \\
leadership & Graduate & 16 & 4.49 & 0.37 & & \\
Managerial & Undergraduate & 43 & 4.35 & 0.37 & -1.516 & .135 \\
leadership & Graduate & 16 & 4.53 & 0.50 & & \\
Ethical & Undergraduate & 43 & 4.01 & 0.38 & -1.887 & .064 \\
leadership & Graduate & 16 & 4.23 & 0.39 & & \\
Political & Undergraduate & 43 & 3.88 & 0.42 & -1.825 & .073 \\
leadership & Graduate & 16 & 4.10 & 0.38 & & \\
Leadership & Undergraduate & 43 & 3.73 & 0.53 & -1.772 & .082 \\
effectiveness & Graduate & 16 & 4.03 & 0.72 & & \\
Corporate & Undergraduate & 43 & 3.61 & 0.42 & -.539 & .592 \\
environment & Graduate & 16 & 3.68 & 0.33 & & \\
\hline
\end{tabular}

According to the results in Table 4, the differences in managerial leadership, ethical leadership, political leadership use, leadership effectiveness perception and corporate environment perception of the provincial directors of youth and sports are not significant according to the educational status ( $p>0.05$ ). It is observed that the level of using transformational leadership is different at statistically significant level ( $p<0.05)$ according to education levels and the transformational leadership levels of those with a graduate degree are higher than those with an undergraduate degrees. 
Table 5. Comparison of the Strategic Leadership Scale Sub-dimension Scores of the Participant Provincial Directors of Youth and Sports by Professional Working Period

\begin{tabular}{cccccccc}
\hline Sub-dimension & $\begin{array}{c}\text { Working } \\
\text { period }\end{array}$ & $\mathbf{N}$ & $\mathbf{X}$ & $\mathbf{S d}$ & $\mathbf{F}$ & $\mathbf{p}$ & $\begin{array}{c}\text { Intergroup } \\
\text { difference }\end{array}$ \\
\hline Transformational & $12-17$ & 19 & 4.27 & 0.32 & & & \\
leadership & $18-23$ & 23 & 4.39 & 0.32 & .750 & .477 & - \\
& $23+$ & 17 & 4.36 & 0.36 & & & \\
Managerial & $12-17$ & 19 & 4.28 & 0.44 & & & \\
leadership & $18-23$ & 23 & 4.46 & 0.42 & 1.234 & .299 & - \\
& $23+$ & 17 & 4.46 & 0.35 & & & \\
Ethical & $12-17$ & 19 & 4.03 & 0.36 & & & - \\
leadership & $18-23$ & 23 & 4.08 & 0.46 & .170 & .844 & - \\
& $23+$ & 17 & 4.10 & 0.34 & & & \\
Political & $12-17$ & 19 & 3.85 & 0.45 & & & \\
leadership & $18-23$ & 23 & 3.96 & 0.46 & .703 & .703 & \\
& $23+$ & 17 & 4.01 & 0.32 & & & \\
Leadership & $12-17$ & 19 & 3.70 & 0.58 & & & \\
effectiveness & $18-23$ & 23 & 3.95 & 0.51 & 1.101 & .340 & \\
& $23+$ & 17 & 3.74 & 0.72 & & & \\
Corporate & $12-17$ & 19 & 3.81 & 0.34 & & & \\
environment & $18-23$ & 23 & 3.61 & 0.41 & 3.736 & .030 & $12-17>23+$ \\
\hline
\end{tabular}

Looking at Table 5, it is seen that there is no significant difference in use of transformational leadership, managerial leadership, ethical leadership, political leadership and leadership effectiveness perception level ( $p>0.05$ ). According to the professional working period, the corporate environment perception levels significantly differ according to the working period ( $\mathrm{p}<0.05$ ). In the corporate environment perception, the perceptions of directors working for 12-17 years about the corporate environment are statistically and significantly higher than the directors working for more than 23 years $(\mathrm{p}<0.05)$.

Table 6. Comparison of the Strategic Leadership Scale Sub-dimension Scores of the Participant Provincial Directors of Youth and Sports by Working Period as a Director

\begin{tabular}{|c|c|c|c|c|c|c|}
\hline Sub-dimension & $\begin{array}{l}\text { Working } \\
\text { Period }\end{array}$ & $\mathbf{N}$ & $\mathbf{X}$ & Sd & $\mathbf{F}$ & $\mathbf{p}$ \\
\hline \multirow{5}{*}{$\begin{array}{l}\text { Transformation } \\
\text { al leadership }\end{array}$} & $0-3$ & 18 & 4.40 & 0.38 & \multirow{5}{*}{1.804} & \multirow{5}{*}{.157} \\
\hline & $4-7$ & 18 & 4.20 & 0.24 & & \\
\hline & $8-11$ & 13 & 4.39 & 0.32 & & \\
\hline & $11+$ & 10 & 4.44 & 0.35 & & \\
\hline & $0-3$ & 18 & 4.44 & 0.52 & & \\
\hline \multirow{3}{*}{$\begin{array}{l}\text { Managerial } \\
\text { leadership }\end{array}$} & $4-7$ & 18 & 4.30 & 0.31 & \multirow{3}{*}{1.442} & \multirow{3}{*}{.241} \\
\hline & $8-11$ & 13 & 4.32 & 0.35 & & \\
\hline & $11+$ & 10 & 4.61 & 0.38 & & \\
\hline \multirow{5}{*}{$\begin{array}{l}\text { Ethical } \\
\text { leadership }\end{array}$} & $0-3$ & 18 & 4.17 & 0.49 & & \multirow{5}{*}{.160} \\
\hline & $4-7$ & 18 & 3.92 & 0.32 & \multirow{4}{*}{1.787} & \\
\hline & $8-11$ & 13 & 4.03 & 0.38 & & \\
\hline & $11+$ & 10 & 4.22 & 0.28 & & \\
\hline & $0-3$ & 18 & 4.00 & 0.57 & & \\
\hline \multirow{3}{*}{$\begin{array}{c}\text { Political } \\
\text { leadership }\end{array}$} & $4-7$ & 18 & 3.81 & 0.30 & \multirow{3}{*}{1.639} & \multirow{3}{*}{.191} \\
\hline & $8-11$ & 13 & 3.88 & 0.39 & & \\
\hline & $11+$ & 10 & 4.14 & 0.21 & & \\
\hline Leadership & $0-3$ & 18 & 3.89 & 0.60 & .219 & .883 \\
\hline
\end{tabular}




\begin{tabular}{ccccccc}
\hline effectiveness & $4-7$ & 18 & 3.78 & 0.54 & & \\
& $8-11$ & 13 & 3.72 & 0.70 & & \\
& $11+$ & 10 & 3.82 & 0.64 & & \\
Corporate & $0-3$ & 18 & 3.82 & 0.45 & & .085 \\
environment & $4-7$ & 18 & 3.57 & 0.34 & 2.321 & \\
& $8-11$ & 13 & 3.49 & 0.32 & & \\
\hline
\end{tabular}

According to the results of Table 6, it has been ascertained that transformational leadership, managerial leadership, ethical leadership, political leadership use levels, leadership effectiveness perception levels and corporate environmental perception levels of the provincial directors of youth and sports participating in the study do not present statistically significant difference $(\mathrm{p}>0.05)$.

Table 7. Analysis of the Strategic Leadership Scale Sub-dimension Scores of the Participant Provincial Directors of Youth and Sports

\begin{tabular}{|c|c|c|c|c|c|c|c|}
\hline & & $\begin{array}{l}\text { Transforma } \\
\text { tional } \\
\text { leadership }\end{array}$ & $\begin{array}{l}\text { Managerial } \\
\text { leadership }\end{array}$ & $\begin{array}{l}\text { Ethical } \\
\text { leadership }\end{array}$ & $\begin{array}{l}\text { Political } \\
\text { leadership }\end{array}$ & $\begin{array}{l}\text { Leadership } \\
\text { effectiveness }\end{array}$ & $\begin{array}{l}\text { Corporate } \\
\text { environment }\end{array}$ \\
\hline $\begin{array}{l}\text { Transformational } \\
\text { leadership }\end{array}$ & $\begin{array}{l}\mathrm{r} \\
\mathrm{p} \\
\mathrm{N}\end{array}$ & 1 & & & & & \\
\hline $\begin{array}{l}\text { Managerial } \\
\text { leadership }\end{array}$ & $\begin{array}{l}\mathrm{r} \\
\mathrm{p} \\
\mathrm{N}\end{array}$ & $\begin{array}{l}.715 \\
.000 \\
59\end{array}$ & 1 & & & & \\
\hline $\begin{array}{l}\text { Ethical } \\
\text { leadership }\end{array}$ & $\begin{array}{l}\mathrm{r} \\
\mathrm{p} \\
\mathrm{N}\end{array}$ & $\begin{array}{c}.673 \\
.000 \\
59\end{array}$ & $\begin{array}{c}.872 \\
.000 \\
59\end{array}$ & 1 & & & \\
\hline $\begin{array}{l}\text { Political } \\
\text { leadership }\end{array}$ & $\begin{array}{l}\mathrm{r} \\
\mathrm{p} \\
\mathrm{N}\end{array}$ & $\begin{array}{l}.668 \\
.000 \\
59\end{array}$ & $\begin{array}{l}.708 \\
.000 \\
59\end{array}$ & $\begin{array}{l}.839^{\ldots} \\
.000 \\
59\end{array}$ & 1 & & \\
\hline $\begin{array}{l}\text { Leadership } \\
\text { effectiveness }\end{array}$ & $\begin{array}{l}\mathrm{r} \\
\mathrm{p} \\
\mathrm{N}\end{array}$ & $\begin{array}{l}.521 \\
.000 \\
59\end{array}$ & $\begin{array}{c}.583 \\
.000 \\
59\end{array}$ & $\begin{array}{c}.446 \\
.000 \\
59\end{array}$ & $\begin{array}{l}.241 \\
.065 \\
59\end{array}$ & 1 & \\
\hline $\begin{array}{l}\text { Corporate } \\
\text { environment }\end{array}$ & $\begin{array}{l}\mathrm{r} \\
\mathrm{p} \\
\mathrm{N}\end{array}$ & $\begin{array}{c}.192 \\
.146 \\
59\end{array}$ & $\begin{array}{c}.231 \\
.078 \\
59\end{array}$ & $\begin{array}{l}.254 \\
.052 \\
59\end{array}$ & $\begin{array}{l}.163 \\
.218 \\
59\end{array}$ & $\begin{array}{c}.341^{\cdots} \\
.008 \\
59\end{array}$ & 1 \\
\hline
\end{tabular}

There is a positive and above-moderate relationship between transformational leadership level and managerial leadership, ethical leadership and political leadership level ( $p<0.05$ ), a positive and moderately significant relationship is found between transformational leadership level and leadership effectiveness perception $(\mathrm{p}<0.05)$ and there is no significant relationship between transformational leadership and corporate environment perception ( $p>0.05$ ). Although there is a positive and highly significant relationship between managerial leadership level and ethical leadership level ( $p<0.05)$, there is a positive and above average relationship between managerial leadership level and political leadership level ( $p<0.05)$. There is a positive relationship between transformational leadership and the leadership effectiveness perception $(\mathrm{p}<0.05)$ and there is no significant relationship between managerial leadership and corporate environment perception ( $p>0.05$ ). While there is a positive and 
highly significant relationship between ethical leadership and political leadership $(\mathrm{p}<0.05)$, there is a positive and moderately significant relationship between ethical leadership and the leadership effectiveness perception $(\mathrm{p}<0.05)$. There is no significant relationship between corporate environment perception and ethical leadership level $(\mathrm{p}>0.05)$. There is no significant relationship between political leadership level, leader effectiveness and corporate environment perception ( $p>0.05$ ). There is a positive relationship between leadership effectiveness and corporate environment perception and this is lower than moderate level ( $p$ $<0.05)$.

\section{Discussion}

Strategic leadership and strategic management have become one of the areas where many researches are carried out today. Developments and changes in the world force institutions and organizations to make short and long-term plan. These plans must focus on solving challenges and problems in the future. Moreover, this situation has established a ground for strategic leaders. With the increasing importance of strategic management and strategic leadership, institutions and organizations have undergone structural adjustments and started to implement fundamental changes. Looking at literature, there are many studies about strategic leadership.

According to the results of Table.1, it is observed that the education levels of the majority of the Provincial Directors of Youth and Sports (72\%) are at the undergraduate level. Moreover, the working period as a provincial director is seen with a rate of $30 \%$ for 4-7 years as countably new. $42 \%$ of the provincial directors are in the $44-50$ age range which can be considered as middle age. In the study of Kaplan (2019) performed on strategic leadership during crisis, it has been determined that 114 of the $(71.7 \%)$ participants have been working for 1 to 5 years in their working place. This finding is supported with data related to the working period of the provincial directors in the institution.

In Table 2, it has been determined that the transformational leadership and managerial leadership levels of the participant provincial directors of youth and sports are high. It can be assumed that the Provincial Directors of Youth and Sports put the interests of the organization in the foreground in their departments and they make strategic and functional planning by using time and resources correctly in terms of managerial leadership. Güçlü, Çoban and Atasoy (2017) have stated that directors should create a positive atmosphere by showing transformational leadership attitudes and give their followers the same vision and a sense of sharing the same thoughts. In a study measuring strategic leadership skills of directors and school organizational learning levels, the results have indicated that transformational leadership behavior has a significant and positive relation (Aydin, 2012). In a study examining the relationship between corporate transformation and strategic leadership in the public sector, it has been expressed descriptively that traditional management understanding can no longer meet the needs of public institutions and organizations and strategic leadership understanding should also be taken into account (Elma, 2010). In the study of Uğurluoğlu (2009) performed on directors, the result that the use of transformational leadership obtained in the transformational leadership sub-dimension increases the chances of directors to be successful coincides with the results of our study. The results obtained from these studies support our study. 
Improvement of the public administration system has recently gained attention not only at the national level but also at an international level considerably. For instance, Uğurluoğlu and Pisapia (2010) have stated that the Government of Turkey organized the 5018 public institutions to improve the public administration in 2003. The main reason for this was the strategic management requirements of public institutions for the development of public institutions on the basis of strategic management. Uğurluoğlu, Çelik and Pisapia (2010) argue that the efficiency of financial management and the development and strengthening of organizational culture and identity can increase the efficiency. In this regard, it can be stated that senior executives in sports organizations affiliated to the public administration have the most important role in creating and developing the organizational identity in the strategic leadership dimension.

As stated in data of Table 3, it has been found that directors in the 44-50 age group have significantly higher levels of using transformational leadership than those in the 28-35 age group in the transformational leadership sub-dimension. The reason can be said that older Provincial Directors are more advanced than the younger ones in terms of the life experiences and they are also more effective in putting it into practice at the same time. Looking at Table 4 , it has been determined that the use levels of transformational leadership have differed statistically and significantly depending on the educational status and the level of using transformational leadership of directors with a graduate degree is higher than those with undergraduate degrees. The results of the study of Kılınçkaya (2013) performed on provincial directors of national education support our study. It can be stated that as the education level of Provincial Directors increases, their success in conveying the organizational goals to the employees and planning and executing the interests of the organization increases. Unlike our study, Yasin (2006) couldn't find a relationship between leadership success and such personal variables as gender and education of the leader.

As Table 6 indicates, it is observed that the corporate environment perception levels of Provincial Directors differ at a statistically significant level according to their professional working period. In the corporate environment perception, the corporate environment perception of directors working as directors for 12-17 years is statistically and significantly higher than those working as directors for $23+$ years. As a result, it can be stated that the longer the time spent in the profession is, the higher the corporate environment perception becomes and the environmental perception develops with the experience gained in the company. According to the results of the study (Akgöz and Engin, 2018), the top 50 companies in Fortune 500 use websites to convey information about corporate environment citizenship to their stakeholders. Well-established companies that have gained experience for many years and have a place in the sector are making a breakthrough by using the corporate environment. In our study, it has been determined that the Provincial Directors with a long working period in the public sector manage the corporate environment more effectively. The data obtained by the researchers and the data related to the institutional environment in our study correspond in direct proportion. Today's leaders are faced with the reality of creating a new leadership framework. Postmodern reality requires leaders who can understand their strategic contexts and retain the confidence, competence, and flexibility to adapt to their organizations. New leader framework requires leaders to change from balance to coordination 
and collaboration (Pisapia et al., 2005: 42).

Strategic management in sports organizations like provincial directorates of youth services and sports will be effective to adopt business logic with its principles, to reposition in order to compete in new management realities for sports organizations and to form an organizational theory that is committed to and compatible with effective management practices (Ulukan, 2005: 77). Considering the fact that as the strategic leadership behaviors of senior executives get higher especially in sports organizations, their ability to manage the organizational changes will develop, this management style develops the skills of the employees and prioritizes change by sharing a vision (Çoban et al., 2019).

\section{References}

Akgöz, B. E., \& Engin, E. (2018). Kurumsal Sosyal Sorumluluk Çerçevesinde Çevresel Vatandaşlik. Erciyes İletişim Dergisi, 5(3), 276-288.

https://doi.org/10.17680/erciyesakademia.355334

Altınkurt, Y. (2007). Eğitim örgütlerinde stratejik liderlik ve okul müdürlerinin stratejik liderlik uygulamalart.

Ann, L., \& Cunliffe, A. L. (2008). Organization theory. Sage puplications, Page 3.

Aydin, M. K. (2012). Kamu ve özel ilköğretim okulu müdürlerinin stratejik liderlik özellikleri ile kurumların örgütsel ögrenme düzeyleri arasındaki ilişki (Unpublished master's thesis). Gazi University Educational Science Institute, Ankara.

Boal, K. B., \& Hooijberg, R. (2000). Strategic leadership research: Moving on. The Leadership Quarterly, 11, 515-549. https://doi.org/10.1016/S1048-9843(00)00057-6

Çoban, Ö., Özdemir, S., \& P1sapıa, J. (2019). 'Top Managers' Organizational Change Management Capacity and Their Strategic Leadership Levels at Ministry of National Education" (MoNE). Eurasian Journal of Educational Research; 81, 129-146. https://doi.org/10.14689/ejer.2019.81.8

Covell, D., \& Walker, S. (2013). Managing sport organizations: Responsibility for performance. Butterworth - Heinemann publications.

https://doi.org/10.4324/9780203550281

Davies, B. J., \& Davies, B. (2004). Strategic leadership. School leadership \& management, 24(1), 29-38. https://doi.org/10.1080/1363243042000172804

Elma, R. (2010). Kamu yönetiminde kurumsal dönüşüm ve stratejik liderlik (Unpublished master's thesis). Karamanoglu Mehmetbey University Social Science Institute, Karaman.

Gareth, R. J., \& Jennifer, M. G. (2016). Contemporary management., 9 bask1, McGraw-Hill Education. New York page 412.

Güçlü, N., Çoban, O., \& Atasoy, R. (2017). Okul yöneticilerinin stratejik liderlik özellikleri ile örgütsel sessizlik arasındaki ilişkinin öğretmen görüşlerine göre incelenmesi. Milli Ĕgitim Dergisi, 46(215), 167-191.

Jennifer M. G., \& Gareth, R. J. (2012). Understanding and Managing Organizational Behavior (6th ed.). Pearson published

Kaplan, B. (2019). Kriz Döneminde Stratejik Liderlik (Yüksek Lisans Tezi), Bahçeşehir Üniversitesi, Sosyal Bilimler Enstitüsü, İstanbul.

Kilinçkaya, B. (2013). Il millî eğitim müdürlerinin stratejik liderlik özelliklerinin araştırması (Unpublished master's thesis). Gazi University Educational Science Institute, Ankara. 
Parker, C. (2004). Strategy and environmental analysis in sport. The business of sport management. John Beech \& Simon Chadwick. Edited by. The Business of Sport Management. First published. Pearson Education Limited. Page 220.

Paul, S., \& Sidney A. N. (1989). Strategic Leaders and Leadership Strategic Management Journal, 10, Special Issue: (Summer, 1989), 51-66. https://doi.org/10.1002/smj.4250100706

Pisapia, J. (2006). Mastering Change in a Globalizing World: New Directions in Leadership, Education Policy Studies Series, The Hong Kong Institute of Educational Research, The Chinese University of Hong Kong.

Pisapia, J., Guerra, D., \& Semmel, E. (2005). Developing the leader's strategic mindset: establishing the measures. Leadership Review, 5, 41-67.

Sönmez, V., \& Alacapınar, F. G. (2018). Örneklendirilmiş Bilimsel Araştırma Yöntemleri. Ankara. Anı Yayınc1lık. Retrieved from https://www.jstor.org/stable/2486582

Torkildsen, G. (2005). Leisure and recreation management. Psychology Press. page 419.

Uğurluoğlu, O. (2009). Hastane yöneticilerinin stratejik liderlik özelliklerinin değerlendirilmesi (Yayınlanmamış Doktora Tezi). Hacettepe Üniversitesi Sağlı Bilimleri Enstitüsü, Ankara.

Uğurluoğlu, Ö., Çelık, Y., \& Pısapıa, J. (2010). Strategic leader actions related to the effectiveness of hospital managers in Turkey. American Journal of Business Research, 3(1), 33-52.

Ülker, M. (2009). Okul yöneticilerinin stratejik liderlik özelliklerine ilişkin öğretmen algıları, (Yayınlanmamış Yüksek Lisans Tezi). Kocatepe Üniversitesi Sosyal Bilimler Enstitüsü, Kocaeli.

Ulukan, C. (2005). Transformation of university organizations: leadership and managerial implications. Turkish Online Journal of Distance Education, 6(4), 75-94.

Watt, D. C. (2003). Sports management and administration. Psychology Press. Page 72-73. https://doi.org/10.4324/9780203380604

Wiscombe, C. A. (2009). Planning, monitoring, controlling and evaluating sports organisations. Sport Management, Edited by Karen Bill. First published in 2009 by Learning Matters Ltd.

Yasin, M. Z. (2006). The Use of Strategic Leadership Actions by Deans in Malaysian and American Universities. Doktora Tezi. Florida Atlantic University. Florida.

\section{Copyright Disclaimer}

Copyright for this article is retained by the author(s), with first publication rights granted to the journal.

This is an open-access article distributed under the terms and conditions of the Creative Commons Attribution license (http://creativecommons.org/licenses/by/4.0/). 